\title{
COMMENTARY: PROPOSALS FOR A NEW FISCAL FRAMEWORK
}

\author{
Jagjit S. Chadha ${ }^{1 \star}$, Hande Küçük ${ }^{2}$ and Adrian Pabst ${ }^{3}$ \\ ${ }^{1}$ Director, NIESR, London, United Kingdom \\ ${ }^{2}$ Deputy Director for Macroeconomic Modelling, NIESR, London, United Kingdom \\ ${ }^{3}$ Deputy Director for Social and Political Economy, NIESR, London, United Kingdom \\ ${ }^{\star}$ Corresponding author. E-mail: J.Chadha@niesr.ac.uk
}

"How did you go bankrupt?"

"Two ways. Gradually, then suddenly."

Ernest Hemingway, The Sun Also Rises (1926)

$[P]$ ublic opinion requires, justly perhaps, that a deliberate plan, and particularly a new plan, should not merely be better than doing nothing, but much better. A new plan is required to meet objections, which apply equally to the old plan. But which in the case of the latter custom has caused us to forget. The new plan is required to satisfy ideals of social justice much higher than we have been attaining without it.

J. M. Keynes, How to Pay for the War (1940)

\section{Towards better fiscal policies}

Modern representative democracy is faced with the Whiggish directive to improve living standards with the main lever in possession of any government being its fiscal policy. That is its choice on how much to spend, tax and borrow and on what. The electorate is supposed to assess the alternate options offered by the political marketplace, and the set of offered policies that most closely match those of the electorate, or more precisely its median voter, will be the basis for the government's fiscal strategy (Persson and Tabellini, 1994). And yet once in office governments are not in control of events and must respond again and again to developments that cannot have been imagined only a few years earlier (e.g. Brittan, 1969). Our recent history alone has produced three extraordinary events in a dozen or so years that have in turn asked for flexibility, and then constrained the operation of fiscal policy: the Global Financial Crisis (GFC), the Brexit vote and the Covid-19 pandemic. As much as a politician wants to be seen as the saviour of the nation, they also do not wish to be seen as the person who suddenly bankrupted the state.

There has repeatedly been a fine line between enabling those democratically elected to make a policy choice and the need to demonstrate a sound approach to the management of the fiscal purse strings (Blackaby, 1978; Britton, 1991; Chadha et al., 2016; Thain and Wright, 1995). Indeed, to support fiscal credibility in the aftermath of the 2008-2009 GFC, the then Chancellor George Osborne implemented two key reforms for the setting of setting fiscal policy. First, in 2010 the Office for Budget Responsibility (OBR) was established as a 'fiscal watchdog', which, inter alia, provides an independent assessment of the long-term sustainability of the public finances and forecasts of the economy and the public finances (Budget Responsibility and National Audit Act 2011). Second, in the post-election 2015 Summer Budget, Chancellor Osborne announced a Charter for Budgetary Responsibility (HM Treasury, 2015). 
Table 1. Fiscal Rules since 2010

\begin{tabular}{|c|c|c|}
\hline Year & Rule & Definition \\
\hline \multirow[t]{2}{*}{2011} & Fiscal mandate & $\begin{array}{l}\text { Achieve cyclically adjusted current balance by the end of forecast period } \\
(2015-2016)\end{array}$ \\
\hline & Supplementary target & $\begin{array}{l}\text { Public Sector Net Debt (PSND) as a percentage of GDP to be falling at a fixed date } \\
\text { of } 2015-2016\end{array}$ \\
\hline \multirow[t]{2}{*}{2012} & Fiscal mandate & $\begin{array}{l}\text { Achieve cyclically adjusted current balance at the end of the forecast period } \\
(2016-2017)\end{array}$ \\
\hline & Supplementary target & PSND to fall as a percentage of GDP between $2014-2015$ and 2015-2016 \\
\hline \multirow[t]{2}{*}{2013} & Fiscal mandate & Achieve cyclically adjusted current balance, 5 years ahead \\
\hline & Supplementary target & Reduce PSND as a percentage of GDP in 2015-2016 \\
\hline \multirow[t]{2}{*}{2014} & Fiscal mandate & Achieve cyclically adjusted current balance, 5 years ahead \\
\hline & Supplementary target & Reduce PSND as a percentage of GDP in 2015-2016 \\
\hline \multirow[t]{2}{*}{2015} & Fiscal mandate & $\begin{array}{l}\text { Borrow only to pay for investment in the third year of the rolling 5-year forecast } \\
\text { period (2017-2018) }\end{array}$ \\
\hline & Supplementary target & Reduce PSND as a percentage of GDP in 2016-2017 \\
\hline \multirow[t]{3}{*}{2016} & Fiscal mandate & Achieve budget surplus in 2019-2020 and beyond \\
\hline & Supplementary target & PSND to fall as percentage of GDP each year \\
\hline & Welfare cap & Spending below cash limits set in July 2015 \\
\hline \multirow[t]{4}{*}{2017} & Fiscal mandate & Structural deficit below 2 per cent of GDP in $2020-2021$ \\
\hline & Welfare cap & $\begin{array}{l}\text { Spending below cash limit in 2021-2022; welfare spending to be below a pre- } \\
\text { defined cap by } 2024-2025\end{array}$ \\
\hline & Supplementary target & Public sector net debt to fall as a percentage of GDP in 2020-2021 \\
\hline & Fiscal objective & $\begin{array}{l}\text { Achieve fiscal balance as soon as possible in next parliament } \\
\text { (2022 or 2025?); overall borrowing to be zero or in surplus by } 2025-2026\end{array}$ \\
\hline \multirow[t]{3}{*}{2019} & Fiscal mandate & $\begin{array}{l}\text { Balancing the current account budget (i.e. excluding capital spending) within } \\
3 \text { years, and remain in balance }\end{array}$ \\
\hline & Supplementary target & A limit of 3 per cent of GDP on Infrastructure borrowing \\
\hline & Supplementary target & $\begin{array}{l}\text { A } 6 \text { per cent of tax revenues trigger for debt interest costs beyond which } \\
\text { government must reassess its borrowing plans with the goal of ensuring debt } \\
\text { does not rise }\end{array}$ \\
\hline
\end{tabular}

That fiscal policy framework set two clear objectives for fiscal policy:

1. to achieve sustainable public financess and

2. to support the effectiveness of monetary policy.

And in support of these objectives, new formal fiscal rules were adopted, which were to be assessed by the OBR but because of their transparency would drive the debate by the media and the public. But the rules were simply not timeless and were changed nearly every year as economic circumstances changed. In a manner reminiscent of the changing targets and measures for monetary aggregates in the 1980s, the variation undermines credibility. Table 1 shows the startling sequence of rules since 2010: 
It is clear is that rules-based policy making may help stabilisation (Chadha and Nolan, 2007) and may support the achievement of meet internal adding-up constraints for expenditure across departments and setting the path for expenditures over time may support the drive for efficiency gains in the public sector. But strict adherence to self-imposed rules also implies that taxes and spending could be adjusted sharply, in response to minor changes in forecast assumptions or in the face of small shocks. Either way, the pursuit of arbitrary public debt and deficit targets can lead to adverse effects on the welfare of citizens and communities.

Besides, the adoption of rules that were subject to considerable year-to-year variance does not really provide the public with a sense of fiscal credibility. To borrow a phrase from monetary economics, policy makers cannot be thought to be working with a timeless rule when it might be expected to change with every new fiscal event (cf. Fetter, 1965; Woodford, 2011).

So, despite elements of the framework succeeding, what are the key problems it faces? Fiscal policy is not a 'one instrument-one objective problem' as it involves a complex constellation of choices over tax, spending and borrowing and the appropriate choice depends on our uncertain knowledge about the state of the economy (cf. Peden, 1988). This means it is both hard to write down a rule that encompasses the choices and the frequency at which those choices are subject to change. Such rules might thus be thought not to be especially binding on future Chancellors and therefore of limited value. Compare this to a simple exchange rate rule where we can say that sterling will equal so many dollars and that is it. Of course, such rules were also broken.

We believe that there are four types of problems with the current fiscal framework (for a summary see Box A):

1. First of all, the political and economic cycle simply do not coincide, so tying fiscal policy to a Parliamentary term is doomed to failure.

2. Secondly, business cycles, like unhappy families, are each different in their own way. They do not operate on a systematically similar basis which means we cannot identify the economic cycle in real time and this creates complexity in understanding the underlying fiscal position.

3. Thirdly, the Chancellor controls too much. There is power over fiscal instruments, messaging and timing in a manner that raises the concern that fiscal choices are unduly sensitive to political rather than economic criteria and may involve a trade-off between the two.

4. Finally, there is no satisfactory definition of the objective of fiscal policy that meets a social welfare objective; at times, the appropriate response might mean increases or decreases in public debt as a share of national income.

The information gaps are clear. Not only do we not know the future, but we also do not understand the present. There needs to be much more formal involvement of outside advice to ensure continuity in policy, but also to support the reputation for fiscal sustainability when flexibility needs to be deployed. It is not wise to centralise power when information is partial (see Bhattacharjee and Holly, 2005; Lombardelli et al., 2005), and mechanisms to test ideas and assess the optimality of political choices must be developed. With the benefit of hindsight from this research, we find it odd that HM Treasury rather than the OBR or another independent body produced an analysis of the effects of Brexit prior to the 2016 referendum.

\section{Box A: The fiscal framework failures.}

1. Fiscal policy rules are tied excessively to the parliamentary term, yet political and economic cycles simply do not coincide.

2. The headline fiscal position depends heavily on a business cycle that is not fully known or understood in real time.

3. Fiscal choices are unduly sensitive to political rather than economic criteria.

4. Fiscal policy has to be assessed in terms of a social welfare function not in terms of a deficit or debt position alone. 
For all these reasons, the current system of fiscal rules simply does not work (Chadha, 2019a and 2020a). And in this chapter, we outline an approach to developing a new fiscal framework. We draw on the experience of fiscal policy under Covid-19 (see Box B) but also on our own original work, and a range of external experts, which examines the need for some change in political institutions, a recognition of the flexibility that events and politics will require, but also the need to respond to shocks (Section 2).

Specifically, we develop five policy proposals (Section 3):

1. we argue for a new approach to fiscal events with a stricter timetable, greater parliamentary scrutiny, a clearer focus on the state of the economy and a more granular analysis of the socioeconomic implications of policy choices;

2. we also suggest that the OBR publish pre-fiscal event reports with key issues to which the Budget and the Autumn Statement should respond;

3. in light of uncertain economic cycles, we argue that the Chancellor should outline government thinking about fundamental fiscal choices in different economic scenarios and the OBR should be encouraged to state whether the policies they condition on are reasonable and aligned with social welfare given the economic outlook;

4. we suggest that HM Treasury creates a new body of independent experts for ex ante advice and ex post evaluation of the key fiscal choices, that we move from descriptive fiscal policy to a formal assessment of normative choices; and

5. we argue that fiscal strategy has to be joined up across the UK and all its constituent parts, with particular attention paid to distributional effects, productivity, well-being and ecological sustainability.

\section{Box B. Case study: guiding principles for fiscal policy in times of Covid-19.}

The economy has been used as an instrument to control the spread of Covid-19. Mass lockdowns across the world have been deployed as a way of limiting the spread of this virus and the UK started its first lockdown on 23 March 2020. The Covid-19 economic crisis introduces what has been called 'radical uncertainty' (Kay and King, 2020), as we do not have complete knowledge about its incidence or duration, but we assumed that it will be likely to be temporary but with more permanent effects. Unlike the 'normal' causes of economic fluctuations, this contraction does not result directly from monetaryfiscal-regulatory laxity and so providing insurance by public policy is not subject to the problem of extensive moral hazard (Chadha, 2020b). Indeed, in large part the economic crisis is the objective of policy in guarding the nation's health. The implication then is that large-scale temporary monetary and fiscal support should be supplied. But who should do what?

The Chancellor's fiscal policy had to decide upon the quantum of risk that the economy faced from which it cannot insure itself, and then the overall level of resources to be transferred across the private sector by taxes and to future generations by debt issuance. It was not so much a question of whether there ought to be a discretionary fiscal response but how much. The key point is that fiscal policy had to consider an actual transfer of resources across households and time that are backed by current and/or future taxes. NIESR's estimates in May 2020 suggested that around a quarter of the economic loss might be met by the immediate response by HM Treasury in March 2020 (Lenoël and Young, 2020). It was important to conserve some remaining space to deal with the high probability of future lockdowns. And accordingly, when the second lockdown (5 November to 2 December 2020) and the third lockdown ( 5 January-to be phased out on 12 April, 17 May and 21 June 2021) were declared, even though the economy proved to be increasingly resilient, fiscal policy was still asked to deal with the return of the virus and the mutated, highly infectious strain B117 of SARS-CoV-2.

It is then a question for the Bank of England to decide whether that quantum of risk and resource transfers undertaken by fiscal policy require any changes in the stance of monetary and financial policies (Tucker, 2018). To that, there is the question of using short-run flexibility subject to the constraint of maintaining credibility, or reputation, which is a critical intangible public sector asset. Indeed, it is typically found that aligning policies to people's long-run expectations of that institution's 


\section{Box B. continued}

behaviour make short-run polices more effective as they avoid problems associated with time inconsistency. Fiscal policy has not progressed in the same way as monetary policy in this regard.

In confronting economic risk and radical uncertainty, in the way Covid-19 has revealed itself, fiscal policy must be prepared to revise its plans regularly in light of news about the spread of the virus and the economic impact here and overseas. It is also a sensible moment to establish more clearly a long-run objective to build up the net worth of public sector balance sheet, alongside a commitment to sustainable levels of public debt within an institutional structure that provides regular scheduled policy planning and projections on the path of the primary fiscal surplus and the debt stock (Chadha, 2021b).

In recent times, monetary policy has been the main lever to stabilise economic fluctuations and support the economy's adjustment to its long-run equilibrium. This has relied on deploying movements in Bank Rate or operations in the money market to influence longer-term interest rates to bring forward or defer expenditure. But the Covid-19 crisis has brought fiscal policy to the forefront of the policy imperative. There are broadly five reasons why we have focussed mainly on fiscal policy in the first instance and deployed it in an active manner:

1. Lockdowns are economic instruments directed at controlling the spread of Covid-19. A significant fraction of the market economy has thus been placed in a state of near suspended animation to prevent a rapid progression of the virus through the domestic and global population and maintain the provision of healthcare services.

2. Lockdowns reduce the overall labour supply, but while there is excess labour supply in some areas such as the recreation, travel and restaurant sectors, there is a shortage in others, for example in healthcare, agriculture and childcare. The state, as in wartime, could help divert labour to areas where required and provide basic training for necessary skills development (Küçük et al., 2020).

3. The economic shock more obviously affects those households who cannot work remotely on a sustained basis, many of whom who are self-employed and those without sufficient savings to sustain expenditure patterns for necessities. This tends to affect those in the lower income deciles, and it is an argument for a considerable effort on re-distributive policies (Bhattacharjee and Lisauskaite, 2020).

4. Using the list of projects identified by the National Infrastructure Commission (NIC, 2018), we could be aiming to bring forward public investment as soon as lockdowns are eased. And a clear conception of 'levelling up' is needed to achieve its objectives (Besley, 2020). If we are heading for a sequence of lockdowns (or a gradual lifting of restrictions that might extend to the summer of 2022), then any projects that can be completed quickly, at the local authority level or for social housing, should be commenced.

5. Finally, when the monetary policy space is constrained and demand falls so rapidly, it seems very likely that fiscal multipliers are quite large-that is for every pound spent the impact on the economy will not be crowding private sector activity out (Chadha, 2021b). Fiscal policy may be more effective in raising economic activity.

\section{Constructing the fiscal jigsaw}

The new fiscal framework must learn these lessons. That it is allowed sufficient flexibility to deal with the news and shocks that arise. Ensure that sufficient instruments are available in terms of debt issuance to allow expenditure to rise where required. Understand that detailed knowledge of localities and regions will best create the conditions for fostering confidence in policies and generating long term multipliers. It is possible to argue that it is because of the lack of formal scrutiny that fiscal policy has been too loose and then too tight over the past quarter of century and may have built up political tensions (see, for example, Fetzer, 2019).

The framework will thus have to generate beliefs, or credibility (cf. North and Weingast, 1989), that policy is forcing positive adjustment in the economy without creating unsustainable paths that will limit abilities to deal with future shocks. We summarise below under several headings the main conclusions from an Occasional Paper (Chadha et al., 2021) recently published by NIESR:

\subsection{Fiscal policy objectives}

A robust fiscal framework requires a clear definition of the fundamental objective, targets and instruments of fiscal policy. The main objectives of fiscal policy are to manage society's risks in the face of major 
socioeconomic shocks and to provide public goods that would otherwise not be supplied to a sufficient degree by the market or the third sector (Coyle, 2020; Rajan, 2019). This implies the retention of some spare fiscal capacity - fiscal space- to deal with, as yet, unresolved future states of the economy (Chadha, 2021c).

Fiscal policy objectives have varied significantly over time. Allen (2021) provides a historical account of what fiscal policy tried to achieve in the post-war era (1945-1970) and how fiscal space was created to finance the ambitious spending plans of post-war governments. Arno Hantzsche's chronological account of the changes in fiscal plans between 1970 and 2018 illustrates how governments' objectives shifted between achieving certain macroeconomic targets and debt stabilisation over past economic and political cycles (Hantzsche, 2021). This applies especially to fiscal consolidation after the end of the Great Moderation - the period of reduced volatility in the business cycle from the mid-1980s to 2007 (Chadha et al., 2016).

At the same time as variation, there has also been some continuity in terms of fiscal policy objectives, targets and instruments. Smoothing the economic cycle and stabilising debt have been the main drivers of fiscal policy (e.g. Pabst, 2021b). One recurrent theme is the centrality of purpose-what exactly is the role of fiscal policy? Byrne (2021) draws lessons from his 2009 experience of planning for fiscal consolidation and emphasises that the government needs to set clear objectives as to what it is trying to achieve when deciding about the right 'tax-spend' mix.

Grice (2021) stresses the importance of considering a more active use of fiscal policy in demand management and a shift towards a genuinely output/outcome focussed spending control system when designing a new fiscal framework. But because fiscal policy cannot deliver any given employment or growth target these are not sensible objectives per se. What fiscal policy can do is to evaluate notions of the appropriate quantity of public expenditure and make decisions on the mix of taxes and borrowing to match that. So some public debate on the path for expenditures and for borrowing is required year on year.

\subsection{Expenditure planning}

A crucial part in the implementation of the fiscal framework is spending control/expenditure planning, which should support internal or cross departmental efficiency. The requirement to meet socioeconomic objectives while retaining fiscal credibility implies that the planning process can be subject to an 'adding up constraint'. Stephen Timms' account of his experience in preparing for the 2007 Comprehensive Spending Review highlights the practical difficulties of allocating a given level of public spending as a ratio to GDP across individual departments, but also stresses the importance of designing mechanisms setting out how departments are expected to contribute to achieving goals set by the government (Timms, 2021).

It is clear that public expenditure flexes in response to economic shocks and to changes in political hue or preferences. Our research shows that public expenditure tends to be revised up (down) following downward (upward) revisions to GDP growth dominated by the effect of automatic stabilisers (Byrne, 2021; Hantzsche, 2021; Pabst, 2021b; Whyte, 2021). This is because of both surprises in the evolution of demand in the short run and as a result of the difficulty of understanding long run trends in potential growth rate of the economy. Fiscal prudence in the form of spending controls or fiscal rules was often achieved by postponing and cutting capital expenditure rather than current spending, as governments generally found the former politically easier, even if it hits national output in times of sluggish economic growth. This long run trade-off needs more transparent exploration.

Expenditure is therefore not fixed and should not pretend to be so. More transparency about the need to respond to a fast-changing environment is required. This should be achieved by the establishment of a robust fiscal framework that combines clear principles for spending (and tax) with state-contingent adjustments. Such a framework has to adopt a medium-term horizon and should favour longer-term investment in physical, human and organizational capital to support the ultimate objectives of fiscal policy: more robust and inclusive growth. 


\section{3. $\operatorname{Tax}$}

The government will seek to raise a present value of taxes that retains the ability to respond to future shocks in a manner that minimises deadweight losses from taxation that distort the supply side.

This means that tax changes need to be smoothed over time and across different activities. This implies episodes of temporarily high public expenditure should be followed by a sequence of budget deficits rather than tax rises. As public expenditure returns to normal, public indebtedness will gradually come down without requiring any adjustment to tax rates provided that the sequence of budget deficits is followed by a sequence of budget surpluses. However, if public expenditure is going to be permanently higher to meet the requirements of long-term structural issues such as aging population, climate change or infrastructure gaps, tax rates will need to be raised accordingly (Chadha, 2021c).

Ellison and Scott (2021) make these points very clearly in the context of the Covid-19 crisis, stressing that the appropriate response to the large temporary shock caused by the pandemic is to let government debt rise to absorb the shock and allow it to stay high for an extended period of time. For the UK, risks associated with high debt are mitigated by the lack of a definitive ceiling to debt, the proven historical record of the UK in dealing with even higher levels of debt, the maturity profile of UK debt, the depth of liquidity and historically low rates of interest.

Another mitigating factor for the UK during the Covid-19 crisis has been that the rise in public deficit has been matched by a rise in private sector savings, which implies increased tax capacity that could be utilised if solvency were to become an issue (Küçük et al., 2020; Lenoël and Young, 2020; Lenoël et al., 2020). This is different to what would have happened if the rise in the deficit had been financed by borrowing abroad, which would have increased the sensitivity of government debt to external financing conditions (Küçük, 2020). These helpful mitigating factors tend to mask the need to strengthen the longterm framework of fiscal policy which is crucial to limit future errors and manage solvency risk.

\subsection{Monetary-fiscal interactions}

In normal times, monetary policy sets the total quantity of nominal expenditure in the economy consistent with price stability and fiscal policy re-distributes activity to meet objectives for the provision of public goods and to limit inequalities to some social norm. In abnormal times, with monetary policy somewhat hampered at the zero or lower bound, there is a prima facie case for monetary and fiscal co-ordination jointly to support economic stability (Chadha et al., 2021). In this case, it means monetary policy creating sufficient fiscal space for governments to be able to act decisively.

Holtham (2021) analyses how and why the conduct of monetary policy, balance sheet policies in particular, affect the size of government debt in the UK, focussing on possible implications of a rise in interest rates for government debt conditional on the Bank of England's preferred actions regarding its reserves and its holdings of government bonds. Accordingly, it is economically justified for the Bank of England to extend its monetary policy instruments further to ensure the lowest possible cost on public finances and communicate this explicitly-as long as inflation control is not compromised. In particular, the significant transactions costs of implementing central bank purchases of government bonds though secondary markets can be reduced by direct operations between the Treasury and the central bank carried out at market prices (Breedon and Turner, 2016).

Lazarowicz (2021) also highlights the interactions between fiscal policy and monetary policy within the context of a simple model of monetary and fiscal policy coordination and suggests that optimal fiscal policy not only must flex in the changing economic conditions, but also condition on monetary policy.

\subsection{Fiscal rules}

A reoccurring theme throughout our work is the requirement for fiscal policy to find a right balance between flexibility to respond to changing socioeconomic circumstances and the credibility to maintain control of debt. Rules-based policies matter for credibility as they impose both external and internal 
discipline and help ensure economic agents condition on the government's plans and allow us to understand progress relative to the plan.

But as our analysis based on interviews with politicians and policy makers shows (Pabst, 2021b), fiscal rules have limited use, both over time and across space, given the difficulties in setting rules that give enough flexibility to respond to unforeseen circumstances and given difficulties in meeting the pre-set targets due to uncertainties in the economic and political background.

Fiscal rules can neither be tied to an unmeasurable and unknown business cycle nor to a political cycle of Parliamentary terms. At some point in the economic and the political cycle, sticking to a set of fiscal rules is likely restrict the flexibility to respond appropriately to changing conditions and might introduce new types of complexity for example due to sanctions for overspend or due to problems of oversight in departmental budget accounting (Chadha, 2019b).

Rules would typically need to be very simple and have clear escape clauses that allow for flexibility in the face of shocks. At the same time as making ad hoc fiscal decisions in response to a fast-changing economic environment, there is also a strong case for a robust fiscal framework that combines clear principles (responsible tax and spend) with state-contingent adjustments (Chadha, 2020a). But given the failure to locate such a rule, we argue for developing the framework and for more explicit policy evaluation.

As stressed by Grice (2021) who provides a detailed account of current fiscal rules and spending controls, the fiscal framework should evolve in a way to focus more on smoothing the economic cycle and on controlling spending with an aim to meet clearly set social and economic objectives. A wider approach to fiscal framework is required, where fiscal sustainability targets focus on public sector net worthtaking into account all of the government's liabilities and assets.

\subsection{Fiscal consolidations}

Following a large expenditure shock, tax smoothing implies some increase in public debt. Indeed, public debt shows very long swings in response to large temporary shocks, the effects of which have been manageable for the UK throughout its recent history owing to the favourable financing conditions including relatively low levels of interest rates and long maturity of debt (Ellison and Scott, 2021).

However, a persistent rise in public debt might leave public policy vulnerable to future shocks. We do not know what they will be, but we do know there will be such shocks. We therefore need to set a course that drives public debt relative to GDP.

Typically though, a large part of the adjustment arises from growth over time in nominal GDP (Allen, 2021; Ellison and Scott, 2021). Discretionary reductions in public expenditure are typically only a secondary part of the consolidation as the upturn in the economic cycle is a more dominant factor. Ultimately, of course a sequence of primary surpluses will provide a rapid reduction in debt to GDP. Setting the appropriate tax and spending composition without losing sight of the ultimate economic objectives is crucial in any consolidation (Byrne, 2021).

\subsection{Instruments}

The government decides on the path of public expenditure and tax revenues which then interact with the business cycle to determine the path of budget deficits (or surpluses) that ultimately determines the accumulation of public debt along with interest payments on debt. More focus needs to be placed on this choice as it reflects the ebb and flow of fiscal decisions. Our analysis shows that there can be significant revisions in spending and revenue plans in relation to revisions to macroeconomic forecasts, change in the views about the economic cycle and changes in government's objectives in response to changing economic circumstances (Hantzsche, 2021; Whyte, 2021).

The type of debt instruments issued, their maturity and how the costs of debt finance move with the economic cycle are also very important for the evolution of debt especially in periods of economic 
distress where budget deficits lead to a rise in public debt. The government's borrowing strategy should aim to contain risks in the future which are dependent on different states of the world. The government can also gain significant fiscal space by its choice of debt instrument and maturity.

There is a large international demand for sterling bonds issued by borrowers with high credit ratings. Pradhan and Turner (2021) therefore stress that the financing government debt depends on conditions in international bond markets, which reduces the sensitivity of the costs of financing new debt to purely local conditions. When choosing the type and maturity of debt, the authorities also need to protect themselves against future changes in the preferences of global investors and in the behaviour of other major government issuers.

In similar vein, we explain that the government can choose and outline more clearly the composition of debt between nominal and index-linked debt, between short- and long-run debts, and between foreign currency and domestic debt. Consideration should also be given to issuing GDP-linked debt, in order to limit payoffs from the bonds issued when the budget deficit is high and output is low (Chadha, 2021c).

Therefore, a clear strategy is required on the optimal composition of debt across different instruments and markets alongside statements about current planned levels of expenditure as the former has important implications about the level of fiscal adjustment (the size of future primary surpluses) that will be required to bring public debt to GDP under control. And may help the process of exiting from quantitative easing.

\subsection{Uncertainty}

Fiscal policy must confront uncertainty by presenting a central case for the path of both GDP growth and debt. Since uncertainty is a fundamental reality of the economy, politics and society, both policy makers and political decision makers need narratives to make sense of numbers (Pabst, 2021a). Amid the white noise of ever-more information (including new, real-time data), sound decision making requires a robust conceptual framework in order to provide clear signals.

Credible, effective fiscal policy depends on the persuasive power of the underlying framework backed by sound theories and concepts as well as all the available empirical evidence (cf. Keynes, 1940 [2010]). Judgement is key as it allows informed decisions about rival models or sets of data based on both history and theory. And judgement requires more than a set of changing rules or targets. It involves a sense of how to go about making both economic and ethical choices in the face of pressing problems (2070 Commission, 2020).

\section{Elements for a new framework}

In the 2021 Budget, the Chancellor Rishi Sunak postponed the adoption of new fiscal rules after effectively abandoning the previous set of rules in 2020 amid the response to the Covid-19 pandemic. While new fiscal rules are yet to be set formally, the following broad principles were announced in the 2021 Budget:

'First, while it is right to help people and businesses through an acute crisis like this one, in normal times the state should not be borrowing to pay for everyday public spending'.

'Second, over the medium term, we cannot allow our debt to keep rising, and, given how high our debt now is, we need to pay close attention to its affordability'.

'And third, it is sensible to take advantage of lower interest rates to invest in capital projects that can drive our future growth'. (Sunak, 2021)

However, as already suggested, the very complexity of fiscal policy makes it fit uneasily with either simple rules or with a one-shot annual presentation of policy at a Budget (Chadha, 2021a); a future fiscal 
framework has to be more robust than past or present arrangements. It ought to be based on a combination of clear principles (a sustainable mix of tax and expenditure) alongside state-contingent adjustments, with a careful explanation of the underlying method of how sequences of primary surpluses or deficits will be managed and achieved. Over time, this will lead to a more considered national and regional debate as to the implications of fiscal policy choices at every level. A broader approach to fiscal framework should then be adopted, where fiscal analysis ought to focus on the consequences for public sector net worth - taking into account all of the government's liabilities and assets—of policy choices.

Any future fiscal framework has to recognize that radical uncertainty about the state of the economy and the underlying fiscal positions will require constant revisions to GDP forecasts and to spending.

Improvements on the current approach will have to resolve the key issues we have identified:

1. Uncertainty is exacerbated by frequent variations in fiscal rules, targets, budget announcements and changes to spending reviews.

2. Fiscal rules and targets that vary according to the electoral cycle rather than the economic cycle, which raises questions about whether fiscal decisions are taken in the light of political calculations and whether due attention is paid to any trade-off between the two cycles.

3. Over-centralisation of decision making, combined with fragmented institutions, implementation difficulties and near-permanent policy churn.

4. Disconnect between the economic objective of fiscal policy and its social welfare function and a concern with public debt as a share of national income.

We propose five building blocks for a future fiscal framework that seeks to address these flaws in the current architecture. Figures 1 and 2 outline the timeline for the new approach for fiscal policy:

(1) The Chancellor should set out a structured timetable for fiscal events and deliver a Budget speech focussed on the state of the economy and on the government's socio-economic objectives that is more extensively debated and scrutinised by Parliament and by a fiscal council.

The Chancellor should adopt and keep to a structured timetable for fiscal events, so that they are not moved for political motives, real or imagined. At the very least, the dates of the two fiscal events per year must be set far in advance (6-12 months, as with the timetable of the Bank of England's Monetary Policy Committee) and planning should proceed to those dates, rather than the customary few weeks' advance notice or cancellation altogether (see figure 1).

A clear commitment to a timetable would help to ensure that fiscal policy is a source of stability and predictability rather than a further factor of uncertainty. This also applies to the Spending Review (SR) and the Comprehensive SR (CSR). Such a timetable, of course, allows for emergency fiscal events in exceptional times such as the Covid-19 pandemic.

The Budget speech should be a speech on the state of the economy responding to the OBR forecast and should clearly lay out the socioeconomic objectives of the government in the short and medium-term, explaining the government's thinking on how to address the key economic challenges facing the country.

The government ought not to preview or leak policies before fiscal events to spin public opinion favourably through the media. Parliament is the appropriate place for the first announcement and for the full scrutiny of the budget and other fiscal policy initiatives. So, although the OBR has shed a welcome light on fiscal planning, accountability and transparency, the setting of fiscal policy can be improved through greater parliamentary oversight; as well as the Chancellor making more time to explain policy choices to the House of Commons Parliamentary Committees (see figure 2).

(2) The OBR, or a separate fiscal council, should publish pre-fiscal event reports with key issues to which the Budget and the Autumn Statement should respond.

The economic prospects are presented by OBR. But policy is set by the Chancellor and HM Treasury. The impact of fiscal policy has a longer duration than the typical term of Chancellors but can also be 


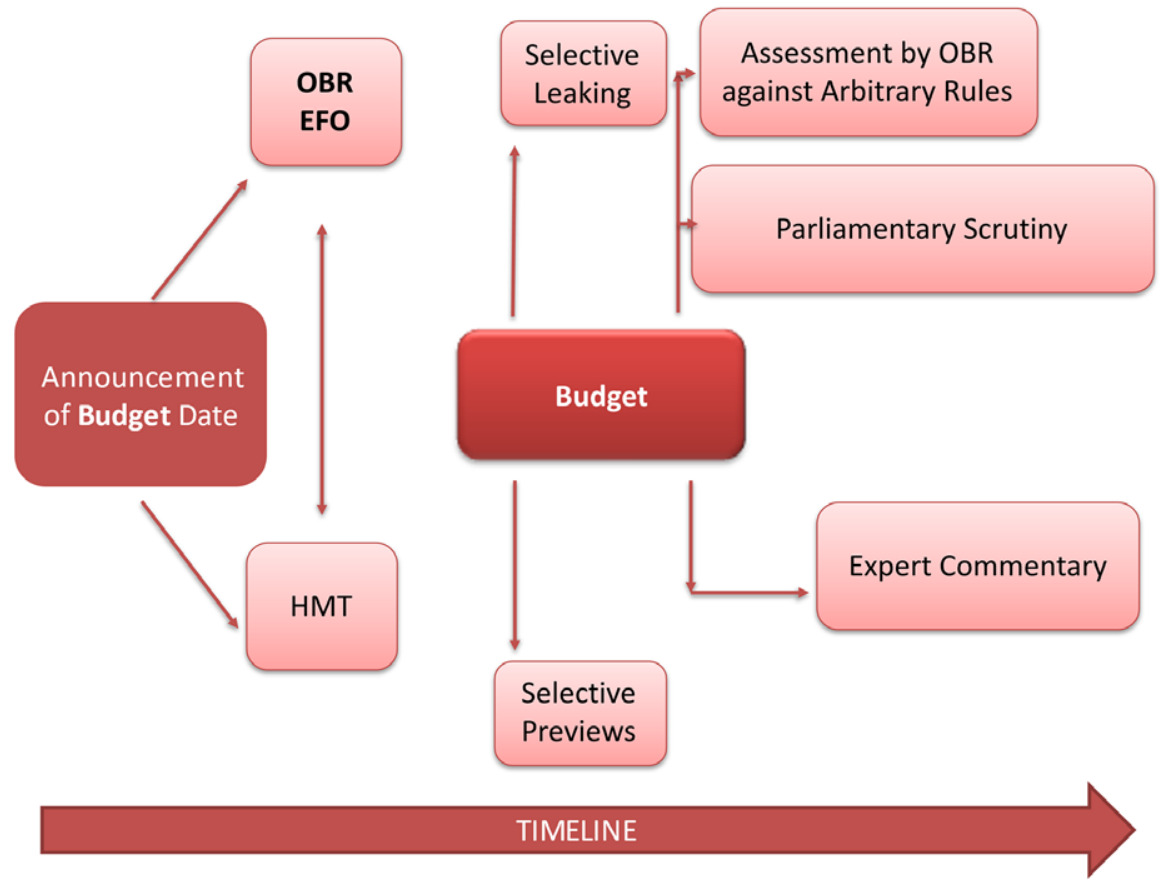

Figure 1. (Colour online) Current schemata of fiscal events

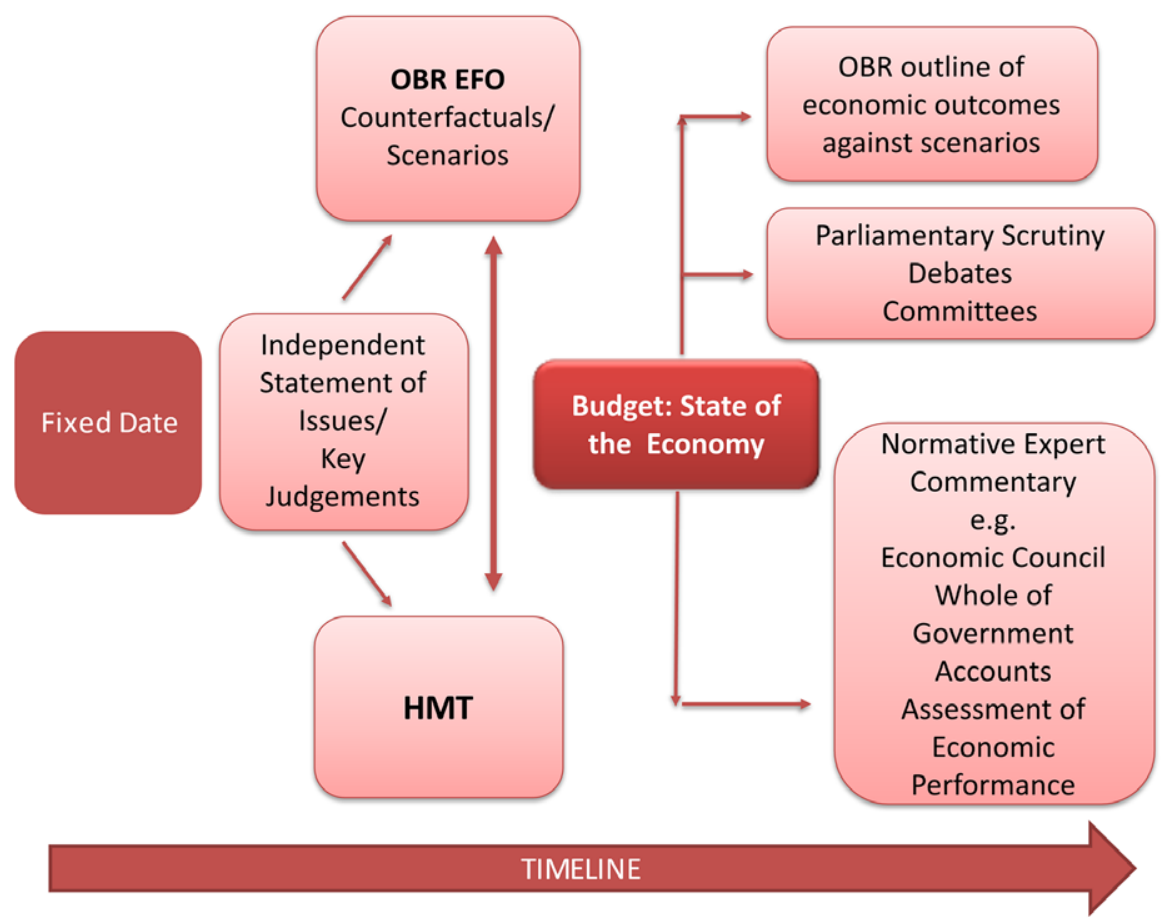

Figure 2. (Colour online) Proposed schemata of fiscal events 
immediate, for example the Coronavirus Job Retention Scheme (CJRS). National income is, of course, the outcome of shocks and policy responses, so we need a more considered and open presentation of economic prospects that outlines where there was news (relative to expectations) and in which areas we need to develop policy. This is a task that should fall to the OBR.

British economic history of the early 21st century, prior to Covid-19, can be characterised by two distinct periods when fiscal policy had been first too loose, prior to the GFC, and then too tight in the period since the GFC. One might even say that on a secular basis that policy has tended to be pro-cyclical.

We would recommend independent pre-fiscal event reports from the OBR that outlined the areas of focus for the Budget or Autumn Statement as a kick-off event for the purdah or budget period. The fiscal event itself would provide some answers to the issues raised by the OBR report. This would also apply to SR/CSR.

(3) Given the uncertainty regarding the economic cycles, the Chancellor should provide more guidance as to how fiscal policy would respond if certain risks materialised and the OBR should produce economic forecasts and scenarios to inform government thinking about fundamental fiscal choices in different states of the world.

The OBR produces detailed forecasts of the UK economy over a 5-year horizon, conditioning the forecasts on assumptions regarding the state of the economy and already announced policies that will be implemented by the HM Treasury. HM Treasury, in turn, decides about the policies to be implemented based on OBR forecasts over the medium term. This partially incomplete, iterative process and the uncertainty around the shocks makes it difficult to track fiscal policy outcomes and gives little guidance as to how policy would respond to changing economic circumstances (see figure 1).

One issue regarding OBR forecasts is that the announced policies that they condition on might be unrealistic. This might lead to public debt and deficit projections that seem in line with government's debt reduction targets even when government spending is unlikely to be kept as low as announced. Hence, the OBR should be encouraged to state whether policies they condition on are reasonable and aligned with social welfare given the economic outlook.

By publishing economic forecasts conditional on a constant path of discretionary fiscal instruments, the OBR could contribute to the understanding of how any new discretionary fiscal policy choices and proposed policy changes relate to the socioeconomic objectives of the government. This exercise would be similar to the Bank of England publishing inflation forecasts conditional on a constant path of interest rates, which signals the adjustment in the interest rate or the overall monetary policy stance that would bring inflation back to the target within the policy horizon.

The fully endogenous forecasts that condition on fiscal policy choices should continue to be produced alongside various economic scenarios to give more guidance as to what the public should expect the Chancellor to do in case some of the risks materialise. Forecasts of the path of debt and deficits under alternative economic scenarios should incorporate not only the automatic stabiliser effects in response to changes in economic circumstances, but also outline how certain discretionary fiscal instruments would evolve to achieve government's objectives in different states of the world.

The communication of the extent to which there is conditionality in fiscal instruments and the associated paths of deficit and debt would contribute a great deal to demonstrating that fiscal policy responds to events and implements state-contingent measures to smooth the economic cycle and maximise social welfare. For example, had the OBR explicitly factored in the extension of CJRS in a risk scenario where there was a second wave of the pandemic to last until the end of the associated lockdowns, and the Chancellor had communicated and committed to such a state-contingent job support scheme, the effectiveness of the scheme would have been amplified through reduced uncertainty and increased confidence.

Another example is how OBR forecasts and scenarios could guide the design of monetary and fiscal policy interaction going forward, given the recent rise in public debt and the significant share that is held by the Bank of England as a result of Quantitative Easing (QE). It is important to examine funding costs 
of existing debt under various economic scenarios, taking into account general equilibrium effects of different economic shocks that could lead to a rise in borrowing costs of the government.

(4) HM Treasury should create a new body of independent experts for ex ante advice and ex post evaluation of the key fiscal choices.

HM Treasury should start the process of budget planning by setting out issues and options for consideration by independent experts. They could be drawn from the National Audit Office or from a beefed-up version of the OBR's advisory panel. This group would form a formal body of policy advice prior to fiscal events and policy evaluation after fiscal events. A fiscal policy evaluation office would add a normative aspect to the watchdog element of the OBR's current role.

Such a new body could be analogous to the SAGE committee and could be modelled on the 'five sages' in the case of the German Council of Economic Experts or the U.S. model of the Council of Economic Advisers appointed by the executive. Regular reports by a stronger fiscal council representing all four home nations would create the conditions for more impartial advice and more informed decision making.

Concretely, the proposed council should include representation from devolved nations and public finance experts to inform decision making and to improve the modelling of the implications of fiscal policy choices for the economies of devolved nations and for the public finances, as well as draw on the evaluation of existing policies in order to improve future policy making.

(5) Fiscal strategy has to be joined up across the UK and all its constituent parts, with particular attention paid to distributional effects, productivity, well-being and ecological sustainability.

New fiscal policies must carefully outline the aggregate and distributional effects, and the impact on regions and the devolved nations. The constituency level impact of policy ought to be presented as part of the Budget or Autumn Statement report. In practice, this means that both HM Treasury and the new fiscal council must pay particular attention to a joined-up approach that takes into account regional, sectoral and household implications of fiscal measures rather than the current approach of overcentralisation combined with fragmentated policy- and decision making.

Over time, the fiscal position also affects the potential growth rate of the economy for better or for worse, and it has important implications for productivity. Therefore, a stronger fiscal council should also analyse and assess the long-term drivers of growth, competitiveness with a special focus on access to finance, dissemination of innovation and its absorption by businesses, as well as the provision of education, skills and training.

Crucially, fiscal targets should not be limited to the pursuit of higher growth but they should also include measures of well-being (as in the case of the 2015 Well-being of Future Generations Act adopted by the Welsh Senedd) and the impact on climate change and bio-diversity.

For a summary of our policy proposals, see Box C:

\section{Box C: A new fiscal framework.}

1. The Chancellor should set out a structured timetable for fiscal events and deliver a Budget speech focussed on the state of the economy and the government's socioeconomic objectives that is more extensively debated and scrutinised by Parliament and a Fiscal Council.

2. The OBR should publish pre-fiscal event reports with key issues to which the Budget and the Autumn Statement should respond.

3. The Chancellor should provide more guidance as to how fiscal policy would respond if certain risks materialise and the OBR should produce economic forecasts and scenarios to inform government on fiscal choices.

4. HM Treasury should create a new body of independent experts for ex ante advice and ex post evaluation of the key fiscal choices.

5. Fiscal strategy has to be joined-up across the UK and all its constituent parts, with particular attention paid to distributional effects, productivity, well-being and ecological sustainability. 
Acknowledgements. We are grateful for conversations with, and comments from, Richard Barwell, Neil Lakeland, Barry

Naisbitt, Philip Turner, Romesh Vaitilingam, Kemar Whyte and Garry Young. Any remaining errors are ours.

\section{References}

2070 Commission (2020), Make No Little Plans. Acting at Scale for a Fairer and Stronger Future, final report, February.

Allen, W.A. (2021), 'Fiscal Space in the Quarter Century After 1945', in Chadha, J.S., Küçük, H. and Pabst, A. (eds), Designing a New Fiscal Framework, London: NIESR Occasional Paper LXI, ch. 2, pp. 31-9.

Besley, T. (2020), 'Better defining "levelling up" is a crucial step to achieving it', National Infrastructure Commission Blog, 6 November 2020.

Bhattacharjee, A. and Holly, S. (2005), 'Inflation targeting, committee decision making and uncertainty: The case of the Bank of England's MPC', Cambridge Working Papers in Economics 0530, Faculty of Economics, University of Cambridge.

Bhattacharjee, A. and Lisauskaite, E. (2020), 'Covid-19 impacts on destitution in the UK', National Institute Economic Review, 253, pp. R77-85.

Blackaby, F.T. (ed) (1978), British Economic Policy, 1960-74, Cambridge: Cambridge University Press.

Breedon, F. and Turner, P. (2016), 'On the transactions costs of quantitative easing', BIS Working Paper no 571, July.

Brittan, S. (1969), Steering the Economy: The Role of the Treasury, London: Secker \& Warburg.

Britton, A.J.C. (1991), Macroeconomic Policy in Britain, 1974-87, Cambridge: Cambridge University Press.

Byrne, L. (2021), 'Fiscal policy choices: The role of informal rules and fiscal frameworks', in Chadha, J.S., Küçük, H. and Pabst, A. (eds), Designing a New Fiscal Framework, London: NIESR Occasional Paper LXI, ch. 8, pp. 99-110.

Chadha, J.S. (2019a), 'It's ridiculous! The disarray of our fiscal system leaves voters short-changed', LSE, 6th December.

Chadha, J.S. (2019b), 'The fiscal rules', Nuffield Election Briefing.

Chadha, J.S. (2020a), 'The chancellor should abandon arbitrary fiscal rules', Financial Times, 22nd February.

Chadha, J.S. (2020b), 'Commentary: Monetary policy in troubled times', National Institute Economic Review, 252, F4-9.

Chadha, J.S., (2021a), 'The March Budget triumph will not solve our deep economic problems', LSE, 3rd March.

Chadha, J.S. (2021b), 'Commentary: Whither after Covid-19 and Brexit: A social science perspective', National Institute Economic Review, 255, 1-8.

Chadha, J.S. (2021c), 'Fiscal policy, uncertainty and debt instruments', in Chadha, J.S., Küçük, H. and Pabst, A. (eds), Designing a New Fiscal Framework, London: NIESR Occasional Paper LXI, ch. 13, pp. 183-9.

Chadha, J.S., Corrado, L., Meaning, J. and Schuler, T. (2021), 'Monetary-fiscal policy complementarities in the Covid-19 pandemic', CFM Working paper.

Chadha, J.S., Crystal, A., Pearlman, J., Smith, P. and Wright, S. (eds) (2016), The UK Economy in the Long Expansion and Its Aftermath, Cambridge: Cambridge University Press.

Chadha, J.S., Küçük, H. and Pabst, A. (eds) (2021), 'Designing a new fiscal framework: Understanding and confronting uncertainty', London: NIESR Occasional Paper LXI.

Chadha, J.S., Kwon, Y. and Shibayama, K. (2021), ‘GDP-Linked Bonds: welfare benefits for hand-to-mouth households', CFM working paper.

Chadha, J.S. and Nolan, C. (2007), 'Optimal simple rules for the conduct of monetary and fiscal policy', Journal of Macroeconomics, 29, 4, pp. 665-89.

Coyle, D. (2020), Markets, State, and People. Economics for Public Policy. Princeton, NJ: Princeton University Press.

Ellison, M. and Scott, A. (2021), 'The debt vaccine', in Chadha, J.S., Küçük, H. and Pabst, A. (eds), Designing a New Fiscal Framework, London: NIESR Occasional Paper LXI, ch. 5, pp. 61-9.

Fetter, F.W. (1965), Development of British Monetary Orthodox, 1797-1875, Cambridge, MA: Harvard University Press.

Fetzer, T. (2019), 'Did Austerity Cause Brexit?' American Economic Review, 109, 11, pp. 3849-86.

Grice, J. (2021), 'The fiscal framework and spending control system', in Chadha, J.S., Küçük, H. and Pabst, A. (eds), Designing a New Fiscal Framework, London: NIESR Occasional Paper LXI, ch. 7, pp. 87-98.

Hantzsche, A. (2021), 'Political revisions to expenditure: Five decades of real-time data on official economic forecasts and UK fiscal policy', in Chadha, J.S., Küçük, H. and Pabst, A. (eds), Designing a New Fiscal Framework, London: NIESR Occasional Paper LXI, ch. 11, pp. 139-70.

HM Treasury (2015), Charter for Budget Responsibility, Autumn update, October, available online at https://assets.publishing. service.gov.uk/government/uploads/system/uploads/attachment_data/file/467082/PU1855_OBR_charter_final_web_Oct_ 2015.pdf.

Holtham, G. (2021), 'Monetary policy and the value of public debt', in Chadha, J.S., Küçük, H. and Pabst, A. (eds), Designing a New Fiscal Framework, London: NIESR Occasional Paper LXI, ch. 6, pp. 71-84.

Kay, J. and King, M. (2020), Radical Uncertainty. Decision-Making for an Unknowable Future, London: Bridge Street Press.

Keynes, J.M. (1940[2010]), Essays in Persuasion, London: Palgrave.

Küçük, H. (2020), Who has Financed Higher Government Spending During the Pandemic? Economics Observatory, 27 November 2020, available online at https://www.economicsobservatory.com/who-has-financed-higher-government-spending-dur ing-pandemic. 
Küçük, H. Lenoël, C. and Macqueen, R. (2020), 'Prospects for the UK economy', National Institute Economic Review, 254, pp. F4-39.

Lazarowicz, T. (2021), 'Monetary-fiscal interactions', in Chadha, J.S., Küçük, H. and Pabst, A. (eds), Designing a New Fiscal Framework, London: NIESR Occasional Paper LXI, ch. 10, pp. 133-7.

Lenoël, C. Macqueen, R. and Young, G. (2020), 'Prospects for the UK economy', National Institute Economic Review, 253, pp. F4-34.

Lenoël, C. and Young, G. (2020), 'Prospects for the UK economy', National Institute Economic Review, 252, pp. F10-43.

Lombardelli, C., Proudman, J. and Talbot, J. (2005), 'Committees versus individuals: An experimental analysis of monetary policy decision making', International Journal of Central Banking, 1, 1, pp. 181-205.

NIC (2018), National Infrastructure Assessment, 10 July, available online at https://nic.org.uk/studies-reports/nationalinfrastructure-assessment/.

North, D.C. and Weingast, B.R. (1989), 'Constitutions and commitment: The evolution of institutions governing public choice in seventeenth-century England', Journal of Economic History, 49, 4, pp. 803-32.

Pabst, A. (2021a), 'Rethinking evidence-based policy', National Institute Economic Review, 255, pp. 85-91.

Pabst, A. (2021b), 'Political organisation of expenditure', in Chadha, J.S., Küçük, H. and Pabst, A. (eds), Designing a New Fiscal Framework, London: NIESR Occasional Paper LXI, ch. 9, pp. 111-30.

Peden, G.C. (1988), Keynes, The Treasury and British Economic Policy, London: Palgrave Macmillan.

Persson, T. amd Tabellini, G. (1994), Monetary and Fiscal Policy, Volumes 1 and 2. Cambridge, MA: MIT Press.

Pradhan, S.-K. and Turner, P. (2021), 'The UK's fiscal deficit: An international perspective on financing', in Chadha, J.S., Küçük, H. and Pabst, A. (eds), Designing a New Fiscal Framework, London: NIESR Occasional Paper LXI, ch. 3, pp. 41-53.

Rajan, R. (2019), The Third Pillar. The Revival of Community in a Polarised World, London: William Collins.

Sunak, R. (2021), 'Budget Speech 2021', 3 March, available online at https://www.gov.uk/government/speeches/budget-speech2021.

Thain, C. and Wright, M. (1995), The Treasury and Whitehall: The Planning and Control of Public Expenditure, 1976-1993, Oxford: Oxford University Press.

Timms, S. (2021), 'Preparing for the 2007 comprehensive spending review', in Chadha, J.S., Küçük, H. and Pabst, A. (eds), Designing a New Fiscal Framework, London: NIESR Occasional Paper LXI, ch. 4, pp. 55-9.

Tucker, P. (2018), Unelected Power. The Quest for Legitimacy in Central Banking and the Regulatory State, Princeton, NJ: Princeton University Press.

Whyte, K. (2021), 'Output and expenditure revisions', in Chadha, J.S., Küçük, H. and Pabst, A. (eds), Designing a New Fiscal Framework, London: NIESR Occasional Paper LXI, ch. 12, pp. 171-82.

Woodford, M. (2011), 'Optimal Monetary Stabilization Policy', in Friedman, B.M. and Woodford, M. (eds), Handbook of Monetary Economics, Volume 3B, Amsterdam: Elsevier.

Cite this article: Chadha, J. S., Küçük, H. and Pabst, A. (2021), 'Commentary: Proposals for a new fiscal framework', National Institute Economic Review, 256, pp. 1-15. https://doi.org/10.1017/nie.2021.14 